\title{
DE ONTWIKKELING VAN DE ACCOUNTANCY IN INTERNATIONAAL VERBAND
}

\author{
door Prof. T. Keuzenkamp
}

Indien men de omvang van het contact tussen de beoefenaren van de accountancy in Nederland met hun beroepsgenoten daarbuiten vergelijkt met het contact bij andere beroepen, dan zal men vaststellen, dat die omvang niet overmatig groot is. Op het gebied van de feitelijke beroepsuitoefening strekt het contact zich niet verder uit dan tot de praktijk van enkele kantoren en op het gebied van de studie beperkt het zich eigenlijk tot de internationale congressen om de vijf jaren. Zowel voor de ontwikkeling van de internationale verbindingen in het beroep, dat toch in feite een international beroep is of moet zijn, als voor de ontwikkeling van de grondslagen voor de meest aangewezen wijze van beroepsuitoefening, acht ik een meer omvangrijk contact onontbeerlijk.

Van jaar tot jaar blijken mij steeds meer de nadelen, die uit dit gemis aan duurzaam contact voortvloeien voor onze beroepsontwikkeling. Wij kunnen datgene, wat de buitenlandse beroepsgenoten als hun taak beschouwen uit sommige studieboeken opdiepen, wij kunnen van sommigen in finesses de wijze leren kennen, waarop zij hun taak uitoefenen, doch tot de kennis van de diepere gronden, die hen tot een afwijkend denkbeeld voeren van wat wij als onze verantwoordelijkheid zien, komen we door kennisneming van deze geschriften niet. Wij weten b.v. niet of een verantwoordelijkheidsgevoel, dat gebaseerd is op het gehoorzamen aan eisen vastgelegd in rechterlijke uitspraken, onze buitenlandse beroepsgenoten bevredigt, of zij bij de bepaling van de beroepsverantwoordelijkheid niet liever van andere beginselen zouden willen uitgaan, doch daartoe niet of niet meer bij machte zijn.

Er zijn voorts erkende beroepsgenoten in andere landen, die een opvatting hebben van de inhoud van hun functie en van de wijze, waarop zij hun taak volvoeren, die niet alleen bij de Nederlandse beroepsgenoten verwondering zal wekken. Zo trof ik in het verslag van de Finse Postspaarbank over het jaar 1952 een accountantsverklaring aan, waarvan $\mathrm{ik}$ hier een vertaling laat volgen, die noodzakelijkerwijze in wat kreupel Nederlands moet luiden om de aard der verklaring beter te doen uitkomen.

A c countantsverklaring.

..De ondergetekenden, die door het Ministerie van Financiën werden aangewezen als accountant voor de Postspaarbank voor het jaar 1952 hebben heden deze onze opdracht voltooid en geven hiervoor de volgende accountantsverklaring af.

Wij hebben het verslag van het bestuur van de Postspaarbank doorgenomen en tevens de balans en resultatenrekening van de bank doorgenomen. Bij de contrōle werd de positie van de bank, de credietgeving en de ontwikkeling ons aangetoond met statistische tabellen en verder heeft men ons van de zijde van de bank alle inlichtingen verstrekt, die wij nodig achtten voor onze opdracht. De interne contrōle van de bank werd naar onze mening met kenis van zaken uitgevoerd en is nu bijzonder effectief. Gedurende het boekjaar zijn leningen verstrekt voor allerlei doeleinden. Steun werd verleend aan de woningbouw en gedurende het laatste half- 
jaar werd daarbij zelfs bijzondere aandacht aan de steun aan bezigheden op de arbeidsmarkt gewijd.

De rekening van het boekjaar werd geopend in overeenstemming met de goedgekeurde balans van het voorafgaande jaar.

Het kastegoed, dat door ons tweemaal werd vastgesteld, benevens de schuldbekentenissen en de voorraad kwitantiezegels, evenals de acten van verstrekte leningen stemden overeen met de in boekhouding opgegeven bedragen.

De boekhouding wordt met zorg geleid en de boekhoudposten baseren zich op de bestaande stukken, zoals wij met steekproeven hebben kunnen controleren.

De onroerende goederen van de bank waren tegen brand verzekerd en de verzekeringen zijn voortdurend van kracht.

De balans is goed afgeleid uit de boekhouding en de balansrekening grondt zich op solide waarden.

Met verwijzing naar het bovenstaande en aangezien de Postspaarbank steeds doelbewust en met goed succes wordt geleid in overeenstemming met haar principes en de bepalingen van de postspaarbankwet, stellen wij voor dat de balans wordt vastgesteld en dat de verantwoordingsschuldigen vrijstelling van verantwoordelijkheid wordt verleend voor het boekjaar 1952 .

Helsinki, 17 Maart 1953".

Niet alleen voor de beroepsontwikkeling bij anderen, doch ook bij onszelf zou een nauwer internationaal contact naar mijn mening goede diensten bewijzen.

Wat onszelf betreft, begint vooral in de latere jaren hier en daar de vraag op te komen of wij zelf wel op de goede weg zijn. In het bijzonder onder de invloed van de Amerikaanse literatuur rijst bij sommige accountants twijfel. Gaan wij op enkele punten bij de vervulling van onze taak niet verder dan nodig is, ja zeker verder dan b.v. volgens Amerikaanse opvattingen is vereist? Men leze hierop de openbare lessen van $\mathrm{Mr} B$. Moret (1945), A. A. de Jong. Ec. drs. (1950), G. Diephuis (1952), A. L. Brok (1953) en het opstel van collega Tempelaar in het M.A.B. 1951 maar eens op na. Er bestaat twijfel in ons midden.

Vraagt men mij op welke wijze dit contact tot stand zou moeten komen, dan geef ik als mijn mening, dat voor dit doel congressen, of grote bijeenkomsten van andere aard slechts gedeeltelijk een oplossing kunnen bieden.

Er zijn er niet zovelen onder de accountants, die naast hun praktijk bereid zijn zich met deze ontwikkelingsarbeid bezig te houden, zelfs niet onder de groep, die het belang daarvan wel inziet. Het gevolg hiervan is, dat men in deze congressen bij voorkeur onderwerpen behandeld wil zien, die op dat moment in de praktijk de aandacht vragen. De ons zo lief zijnde vertrouwenstheorie van Prof. Dr Limperg, in 1926 uitvoerig behandeld in het internationale congres heeft het in meer dan 25 jaar nog niet veel verder gebracht dan tot aan de grenzen van ons land en $z i j$ is toch waard verder bekend te zijn. Bovendien kunnen deze congressen wegens de voorbereidingstijd en de kosten slechts eenmaal in de 4 of 5 jaar worden gehouden.

Naar mijn mening moet getracht worden de ontwikkeling in internationaal verband te bevorderen door het vormen van officieuse internationale studiegroepen, die vaker bijeenkomen en over een of meer 
bepaalde onderwerpen uitputtend van gedachten wisselen. International Committees on auditing research. Hun opdracht moet zijn een gemeenschappelijk rapport van hun bevindingen over een bepaald onderwerp op te stellen dat geen aanbevelingen bevat doch de materie en de afwijkingen op vergelijkbare wijze duidelijk maakt, zodat daarin een basis kan worden gevonden voor een discussie en verdere bestudering allereerst in de betrokken landen en uiteraard ook elders. Zoals de verhoudingen nu liggen, $z$ al het nimmer tot zulke discussies komen, omdat men vreemd staat en blijft staan tegenover de uitgangspunten, die de opvattingen beheersen.

In niet te grote omvang wat het aantal deelnemers en het aantal deelnemende landen betreft begonnen, onderwerpen behandelend, die vooral in de eerste tijd met grote zorg gekozen dienen te worden, zie ik hierin het middel om te komen tot grotere gelijkmatigheid in de eisen in verschillende landen aan een goede beroepsuitoefening te stellen en tot diepere kennis van elkanders bedoelingen. Begonnen moet worden met contact te leggen tussen beroepsgenoten in die landen waar de beroepsuitoefening op vergelijkbaar niveau staat.

Later kan vergroting van het geografisch vlak worden overwogen.

Er zijn natuurlijk bezwaren tegen deze gedachte aan te voeren. De geografische afstanden, die de deelnemers scheiden, zullen eisen, dat $z i j$ meerdere dagen achtereen hun andere werk in de steek laten; de kosten zullen vrij hoog zijn enz., maar ik houd mij ervan overtuigd, dat in Nederland zeker beroepsgenoten zijn te vinden, die het tijdoffer willen brengen en dat de beroepsvereniging, die reeds zoveel offers voor de beroepsontwikkeling heeft gebracht, ook deze kosten zal willen dragen.

Voor dit laatste zal alleen nodig zijn, dat zij, die verkondigen, dat deze internationale samenwerkingen alleen in het belang zijn van de grote kantoren, overtuigd worden van de onjuistheid van hun bewering. Geen enkel beroep dat op wetenschappelijke basis wordt uitgeoefend kan tot volle ontplooiing komen, indien het zijn wetenschap put uit een beperkte sfeer. Een zo ruim mogelijke en een diepgaande aanraking met de gehele wereld is daartoe nodig. Dit streven naar het vinden van over de gehele wereld geldende wetenschappelijke beroepsopvattingen voorkomt niet alleen denigrerende vergelijkingen tussen beroepsgenoten van verschillende landen, gelijk thans bij herhaling voorkomt, doch moet in het verkeer tot hogere waardering leiden van alle beoefenaren zowel van de enkeling als van hen, die werken in groepsverband. Hier zit het grote belang voor ieder.

Zou Nederland, dat reeds op zovele gebieden op internationaal terrein het initiatief nam, ook hier het initiatief kunnen ontwikkelen? 